\title{
Water Quality and Heavy Metal Analysis of Kunchenahalli Lake in Shivamogga District, Karnataka, India
}

\author{
Ganesh Prasanna S \\ Assistant Professor, \\ Department of Civil Engineering \\ J.N.N. College of Engineering \\ Navule, Shivamogga : 577204
}

\author{
Shashikumar M. Hiremath \\ Assistant Professor, \\ Department of Civil Engineering \\ J.N.N.College of Engineering \\ Navule, Shivamogga : 577204
}

\begin{abstract}
An attempt has been made to evaluate the Physico Chemical Parameters and heavy metals in the water and sediment samples of Kunchenahalli lake in Shivamogga District, Karnataka. Water and soil samples were collected during pre-monsoon from January 2019 to April 2019 and subjected to Physical and Chemical analysis viz., Dissolved Solids, pH, Dissolved Oxygen, Total Hardness, Acidity, Alkalinity, Turbidity and Heavy metals. The results indicate that the Lake is contaminated with high concentrations of Iron and Manganese, threatening to use of lake water for the Domestic and Irrigation purposes and also for survival of aquatic flora and fauna.
\end{abstract}

Keywords:- Physico-Chemical Parameters; Heavy Metals; Topo sheet; Atomic Absorption Spectrometry.

\section{INTRODUCTION}

Land uses and the water quality of adjacent aquatic systems within a watershed area shows strong bonds exists between them. Recently, studies of the relationships between land uses and water quality begun to increase considerably (Sang-Woo Lee et.al., 2009). Fe and $\mathrm{Mn}$ are essential minerals, neurotoxicity by inhalation/digestion of these minerals have been widely described, particularly in workers and miners, where exposure is relatively high. Recently, there has been concern over a number of studies that have suggested that exposure to high concentrations of $\mathrm{Fe}$ and $\mathrm{Mn}$ in drinking water may have neurological adverse effects in terms of intellectual and cognitive development. (Paul Rumsby et.al., 2014). Water is one of the most important components of the ecosystem, the increased human population, industrialization, use of fertilizers in the agriculture and man-made activity has deteriorated the quality of the surface as well as ground waters rendering them to unfit for usage. Moreover in addition to this the increase in the levels of heavy metals has enormously summed up a threat to the aquatic and human races. It is therefore necessary that the quality of water should be checked at regular time of intervals.

The Present Study involves the Analysis of water Quality in Terms of Physico-chemical parameters and Heavy metals detection of Kunchenahalli Lake, Shivamogga District, Karnataka. It is located in 14.06 'N, $75.55^{\prime} \mathrm{E}$ and is covered in 48N/12 Toposheet of Survey of India. This Lake is having an area of $4 \mathrm{sq} \mathrm{kmtrs}$ and serving around 5000 population with 1300 households in Kunchenahalli village. This Lake water is used basically for agriculture and partially for domestic activities. The mean annual rainfall in the study area is $901 \mathrm{~mm}$ during the period from 1991-2005.

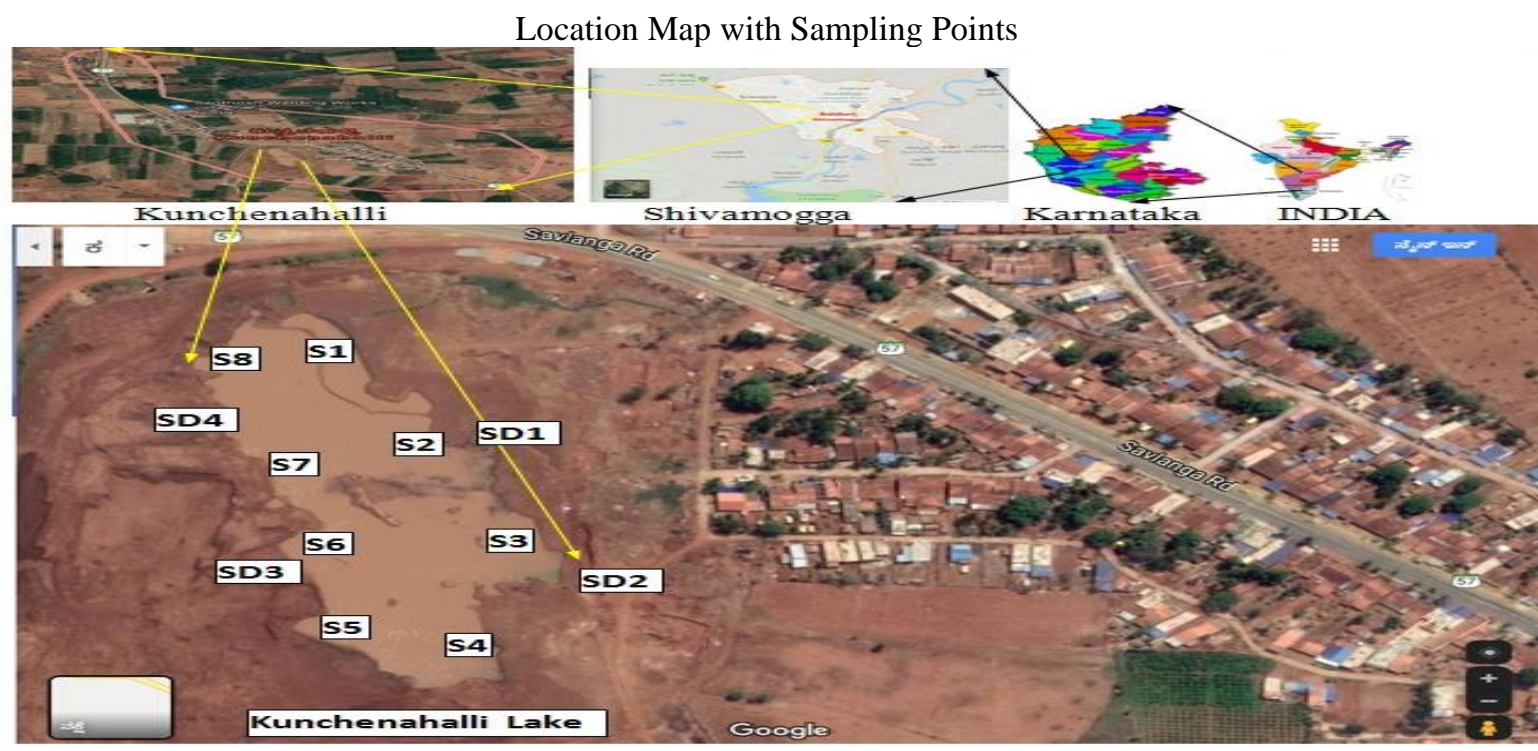

Figure 1: Location map with Sampling points for water samples and soil samples at Kunchenahalli Lake 


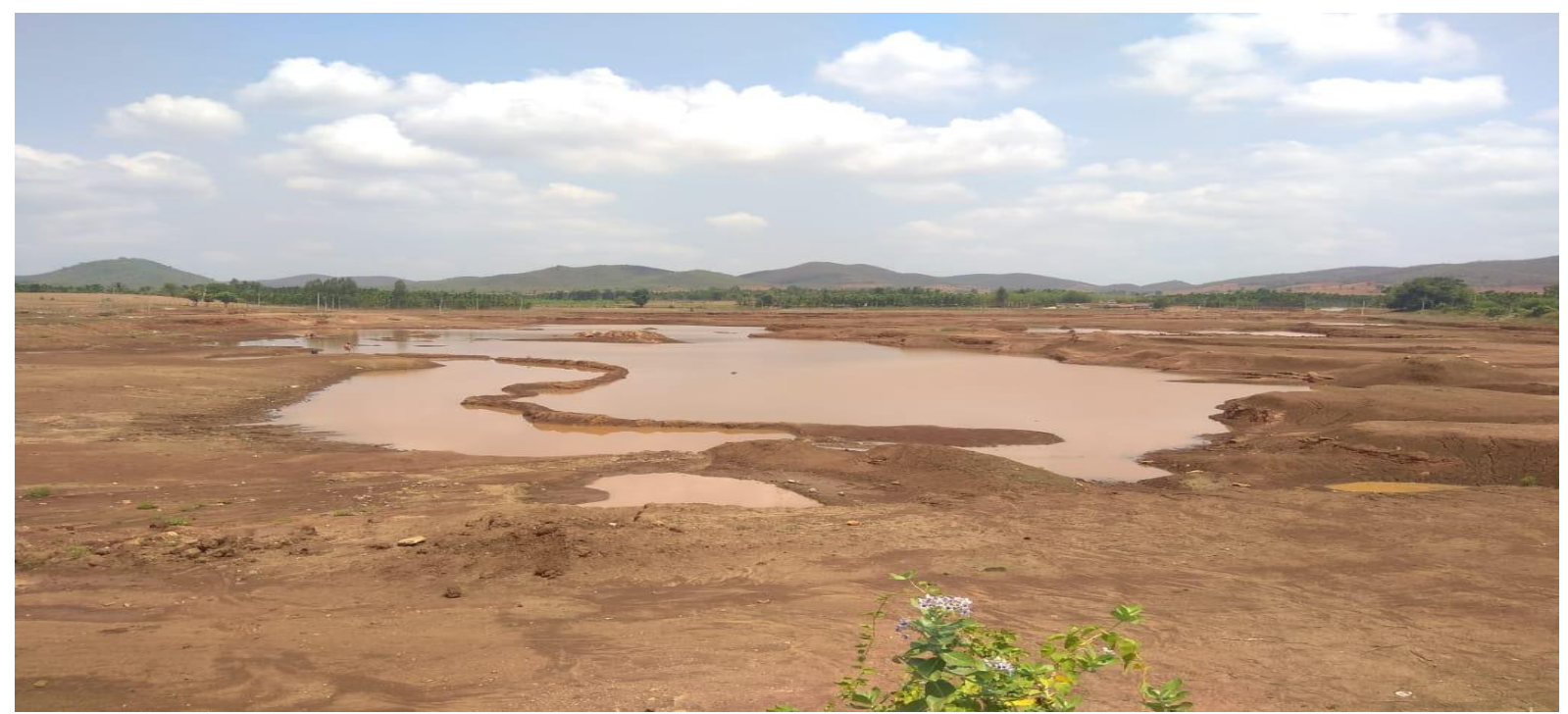

Figure 2: Photographical picture of Kunchenahalli Lake

\section{MATERIALS AND METHODS}

Eight Water samples and Four Soil Samples from Kunchenahalli Lake were collected during the months from January 2019 to April 2019 in clean and dry Polythene bottles. The Water samples and soil samples were immediately brought in to Laboratory for the Estimation of various Physico-chemical parameters. Whereas $\mathrm{pH}$ and DO was recorded at the time of sample collection by using Pocket Digital pH Meter and DO meter. While other Parameters Such as TDS, Hardness, Alkalinity, Acidity and heavy metals such as $\mathrm{Fe}, \mathrm{Mn}, \mathrm{Cu}$ and $\mathrm{Zn}$ were estimated in the Laboratory by using Indian Standard Procedures (Titration method, Atomic Absorption Spectrophotometer (AAS) Thermo M5 Model) (Trivedy and Goel,1986, APHA 1985).

\section{RESULTS AND DISCUSSIONS}

Table 5.1 Physico-Chemical Characteristics of Kunchenahalli Lake Water Samples :

\begin{tabular}{|c|c|c|c|c|c|c|c|c|c|c|}
\hline $\begin{array}{l}\text { SL } \\
\text { No. }\end{array}$ & Samples & Colour & $\begin{array}{c}\text { Turbidity } \\
\text { NTU }\end{array}$ & $\mathbf{p H}$ & $\begin{array}{c}\text { TDS } \\
(\mathrm{mg} / \mathrm{L})\end{array}$ & $\begin{array}{l}\text { Acidity } \\
\text { (mg/L) }\end{array}$ & $\begin{array}{c}\text { Ca } \\
\text { Hardness } \\
(\mathrm{mg} / \mathrm{L})\end{array}$ & $\begin{array}{c}\text { TH } \\
(\mathrm{mg} / \mathrm{L})\end{array}$ & $\begin{array}{c}\text { DO } \\
(\mathrm{mg} / \mathrm{L})\end{array}$ & $\begin{array}{c}\text { Alk } \\
(\mathbf{m g} / \mathrm{L})\end{array}$ \\
\hline 01 & Sample 1 & 10 & 4 & 8.76 & 155.62 & 40.13 & 100 & 200 & 1.54 & 200.12 \\
\hline 02 & Sample 2 & 10 & 4 & 8.87 & 162.44 & 30.33 & 131 & 206 & 1.80 & 205.32 \\
\hline 03 & Sample 3 & 10 & 4 & 8.91 & 160.58 & 40.12 & 106 & 194 & 2.05 & 200.23 \\
\hline 04 & Sample 4 & 10 & 4 & 8.67 & 156.24 & 30.66 & 135 & 204 & 1.71 & 205.00 \\
\hline 05 & Sample 5 & 10 & 4 & 8.71 & 159.34 & 36.21 & 124 & 187 & 1.85 & 190.33 \\
\hline 07 & Sample 7 & 10 & 4 & 8.85 & 160.58 & 36.51 & 126 & 185 & 1.70 & 190.63 \\
\hline 08 & Sample 8 & 10 & 4 & 8.54 & 159.96 & 40.36 & 115 & 171 & 1.90 & 170.28 \\
\hline 09 & BIS (max) & 5 & 1 & 8.5 & 500 & - & - & 200 & - & 100 \\
\hline
\end{tabular}

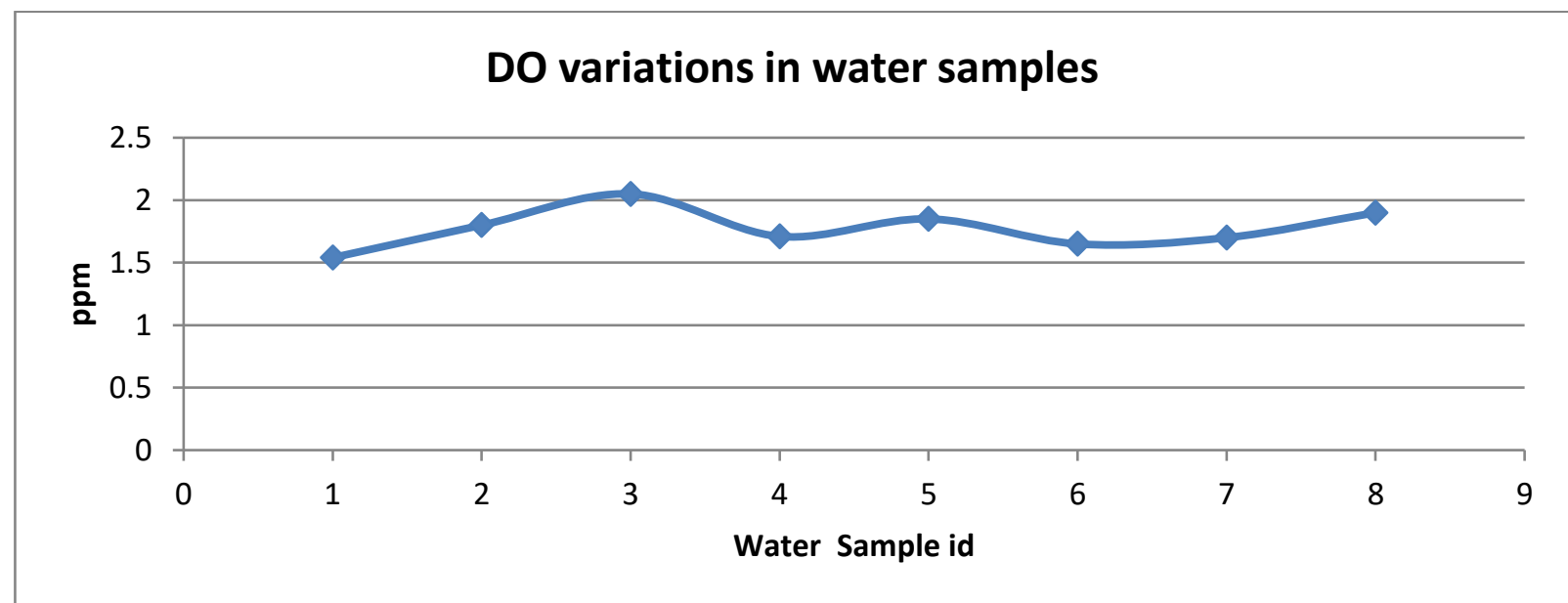

Fig : 5.1.1 DO variations of Kunchenahalli Lake Water Samples 


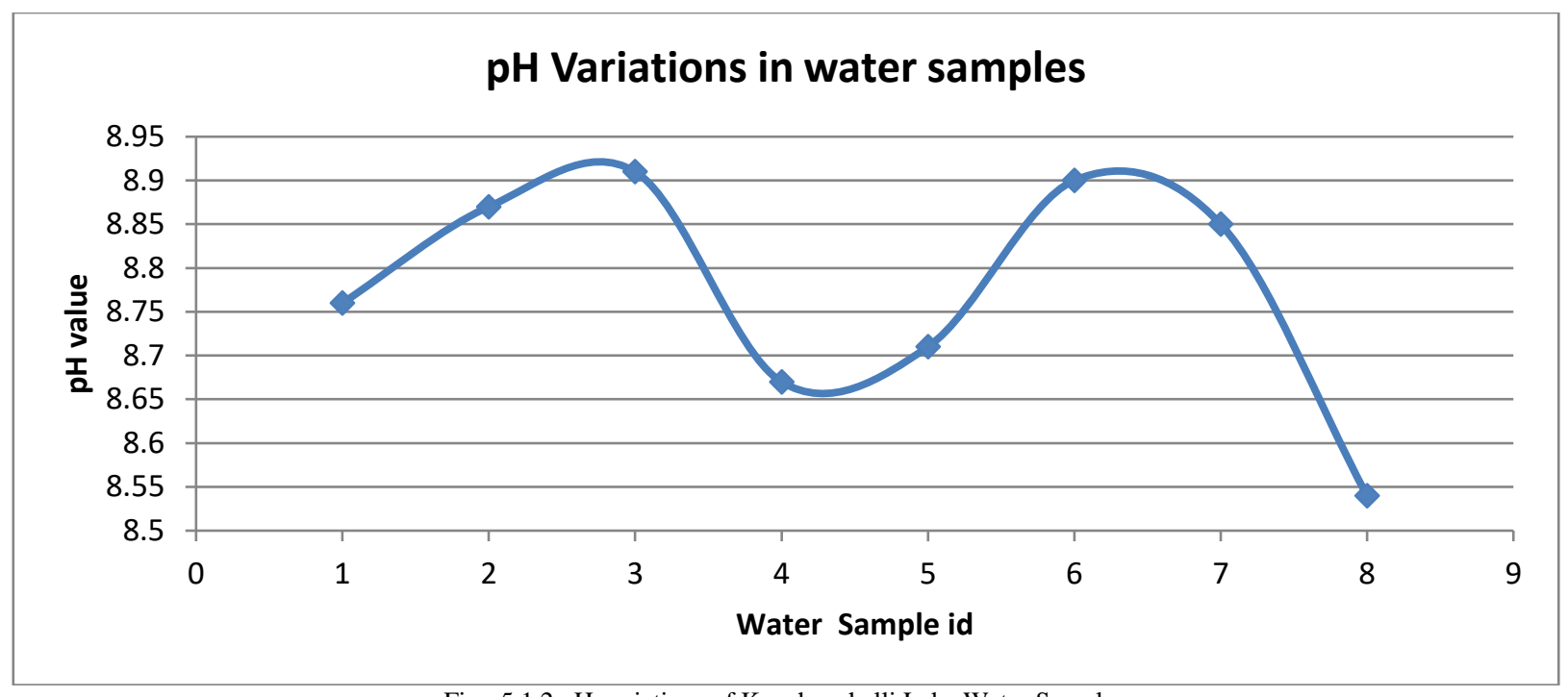

Fig : 5.1.2 pH variations of Kunchenahalli Lake Water Samples

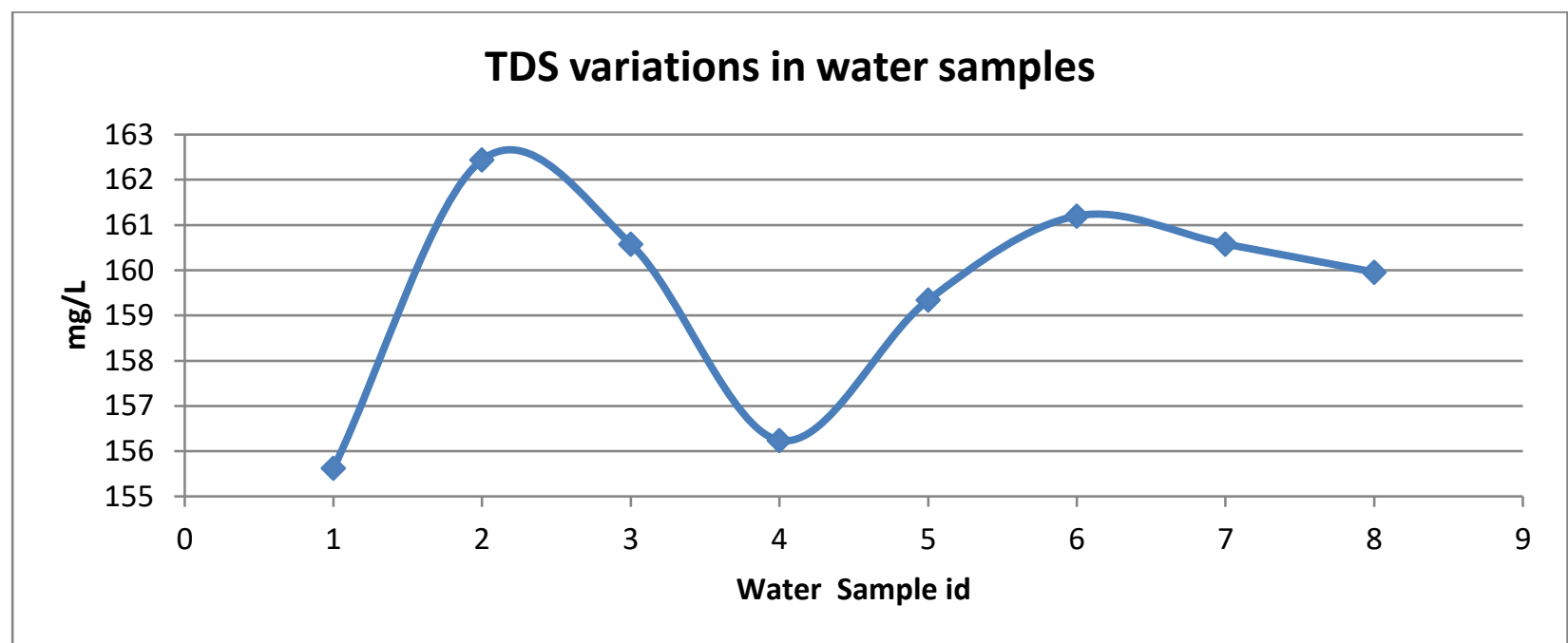

Fig : 5.1.3 TDS variations of Kunchenahalli Lake Water Samples

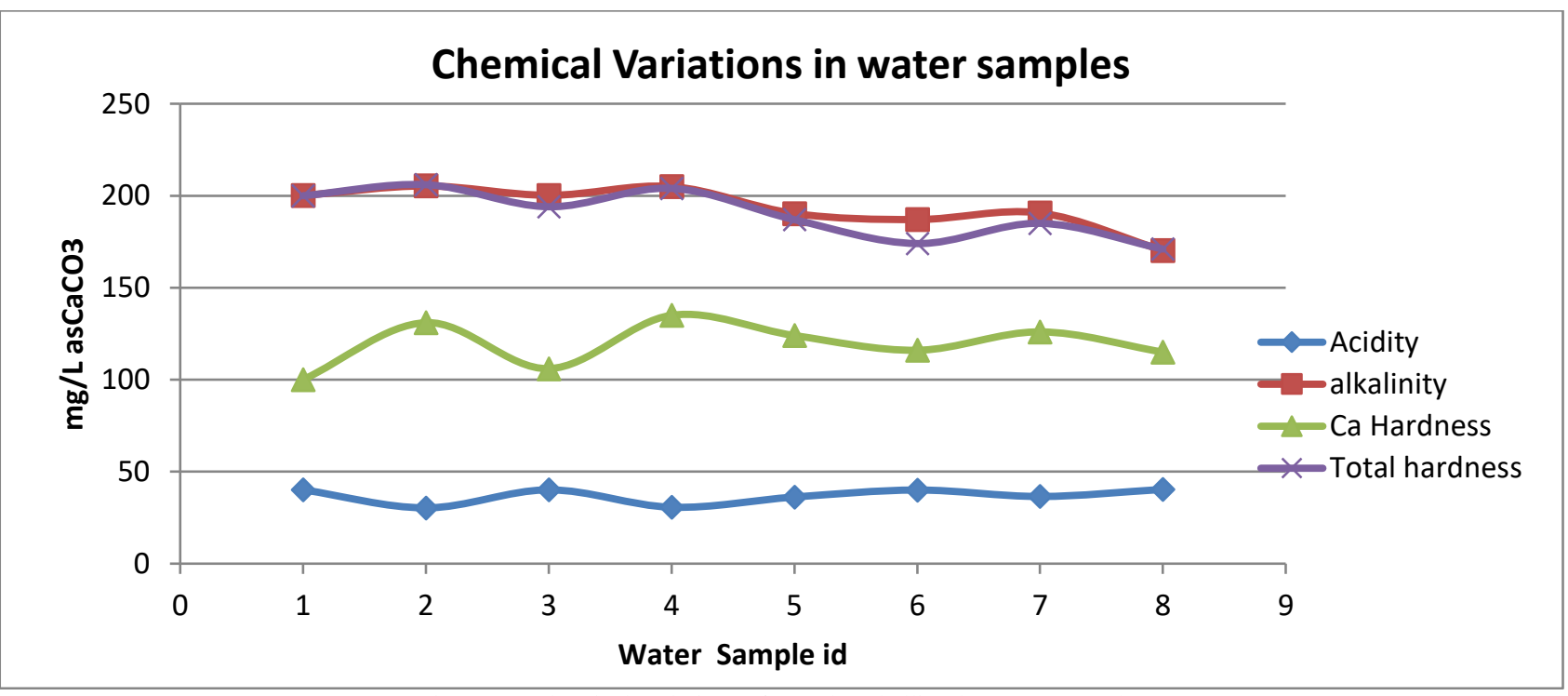

Fig : 5.1.4 Chemical variations of Kunchenahalli Lake Water Samples 
The Physico-chemical analysis of Kunchenahalli Lake water samples (samples taken at the surface level) exhibited normal distribution (Table 5.1) varying in between 8.54 to 8.91 for $\mathrm{pH}$ (Fig 5.1.2) and varying between $155.62 \mathrm{mg} / \mathrm{L}$ to 162.44 $\mathrm{mg} / \mathrm{L}$ for Total Dissolved Solids (Fig 5.1.3) within permissible BIS standard levels 8.5 (pH) and 500 mg/L (TDS). Slightly high values of Total Hardness i.e., $200 \mathrm{mg} / \mathrm{L}, 206 \mathrm{mg} / \mathrm{L}$ and $204 \mathrm{mg} / \mathrm{L}$ for sample no. 1,2 and 4 respectively (Fig 5.1.4) have been reported against BIS standard limit $(200 \mathrm{mg} / \mathrm{L})$ indicating mineral contamination. Lake water is augmented with pollutants reflecting in Dissolved Oxygen analysis of all samples being reported with less DO varying between $1.54 \mathrm{mg} / \mathrm{L}$ to $2.05 \mathrm{mg} / \mathrm{L}$ (Fig 5.1.1) making water body unfit for the survival of aquatic flora and fauna.

Table $5.2 \quad$ Chemical Characteristics of Water at $10 \mathrm{~m}$ Depth

\begin{tabular}{|c|c|c|c|c|c|c|c|c|}
\hline $\begin{array}{l}\text { SL } \\
\text { NO }\end{array}$ & $\begin{array}{l}\text { SAMPLE } \\
\text { DETAILS }\end{array}$ & pH & $\begin{array}{c}\text { Turbidity } \\
\text { NTU }\end{array}$ & pH & $\begin{array}{c}\text { TDS } \\
(\mathrm{mg} / \mathrm{L})\end{array}$ & $\begin{array}{l}\text { Acidity } \\
\text { (mg/L) }\end{array}$ & $\begin{array}{c}\text { Ca Hardness } \\
(\mathrm{mg} / \mathrm{L})\end{array}$ & $\begin{array}{c}\text { TH } \\
(\mathrm{mg} / \mathrm{L})\end{array}$ \\
\hline 01 & Sample 1 & 8.7 & 164.32 & 40.44 & 115 & 215 & 1.31 & 204.65 \\
\hline 02 & Sample 2 & 8.7 & 161.34 & 31.21 & 133 & 223 & 1.56 & 210.12 \\
\hline 03 & Sample 3 & 8.9 & 167.68 & 41.32 & 111 & 201 & 1.89 & 202.90 \\
\hline 04 & Sample 4 & 8.7 & 156.28 & 30.44 & 145 & 208 & 1.52 & 207.27 \\
\hline 05 & Sample 5 & 8.5 & 157.24 & 38.32 & 132 & 200 & 1.77 & 194.21 \\
\hline 06 & Sample 6 & 8.81 & 170.20 & 40.07 & 127 & 196 & 1.45 & 189.11 \\
\hline 07 & Sample 7 & 8.75 & 159.58 & 38.21 & 121 & 201 & 1.59 & 194.32 \\
\hline 08 & Sample 8 & 8.64 & 160.96 & 41.45 & 125 & 213 & 1.61 & 181.32 \\
\hline 09 & BIS(max) & 8.3 & 500 & - & - & 200 & - & 100 \\
\hline
\end{tabular}

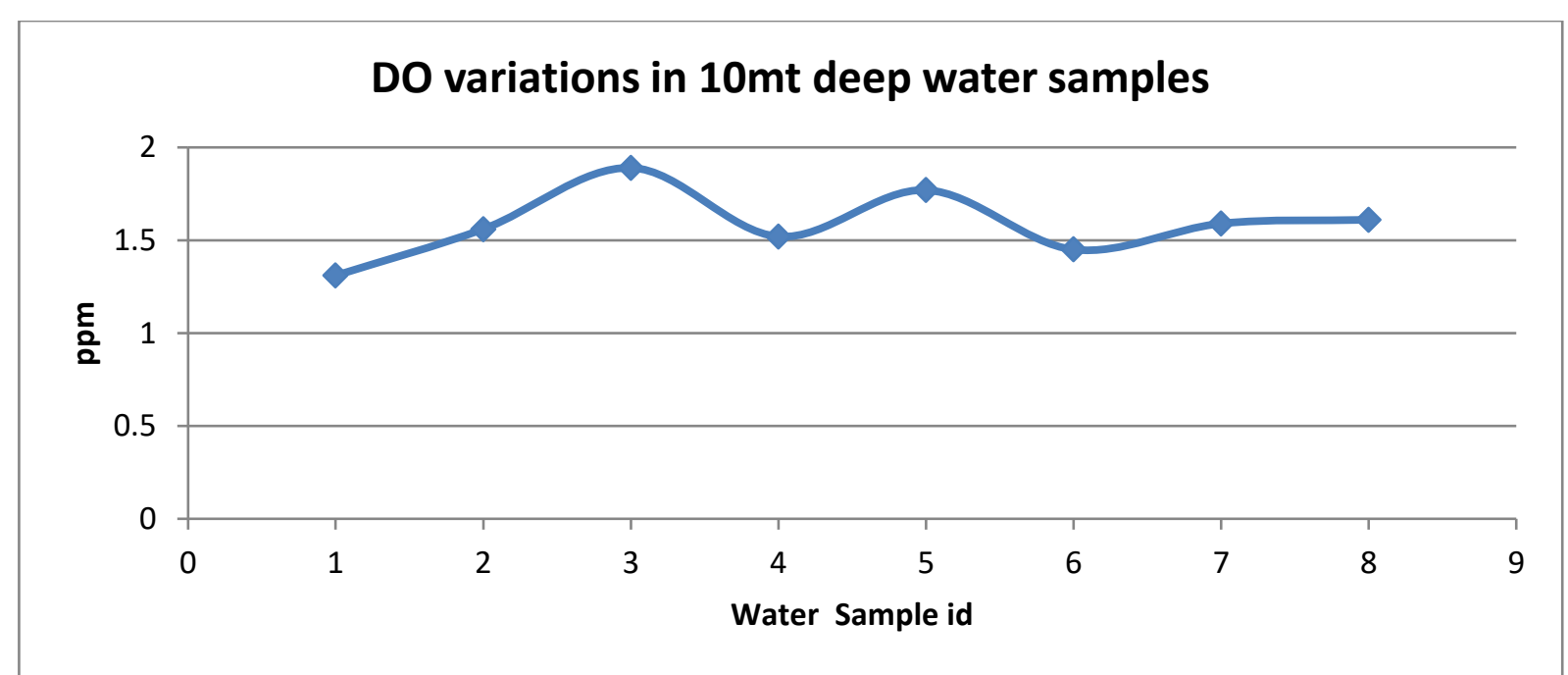

Fig : 5.2.1 DO variations of Kunchenahalli Lake Water Samples (10mt Deep)

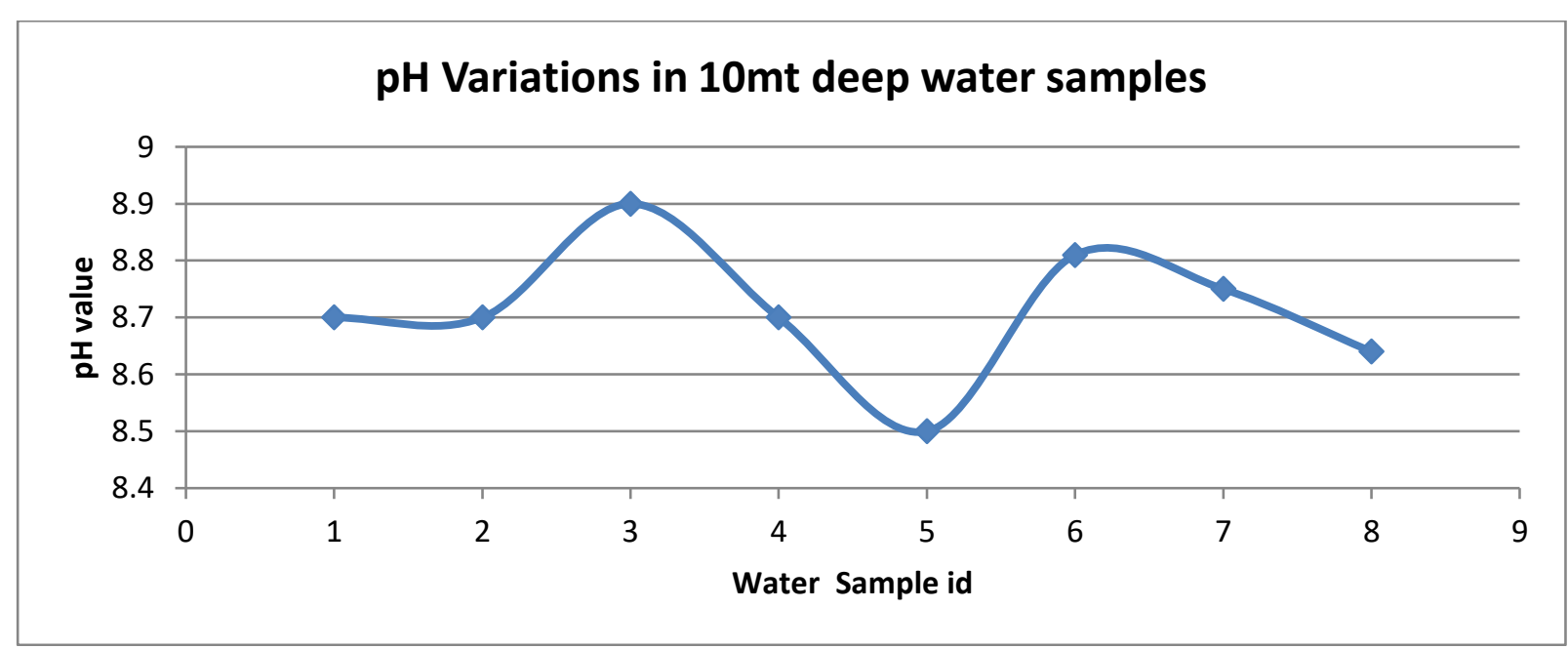

Fig : 5.2.2 pH variations of Kunchenahalli Lake Water Samples (10mt Deep) 

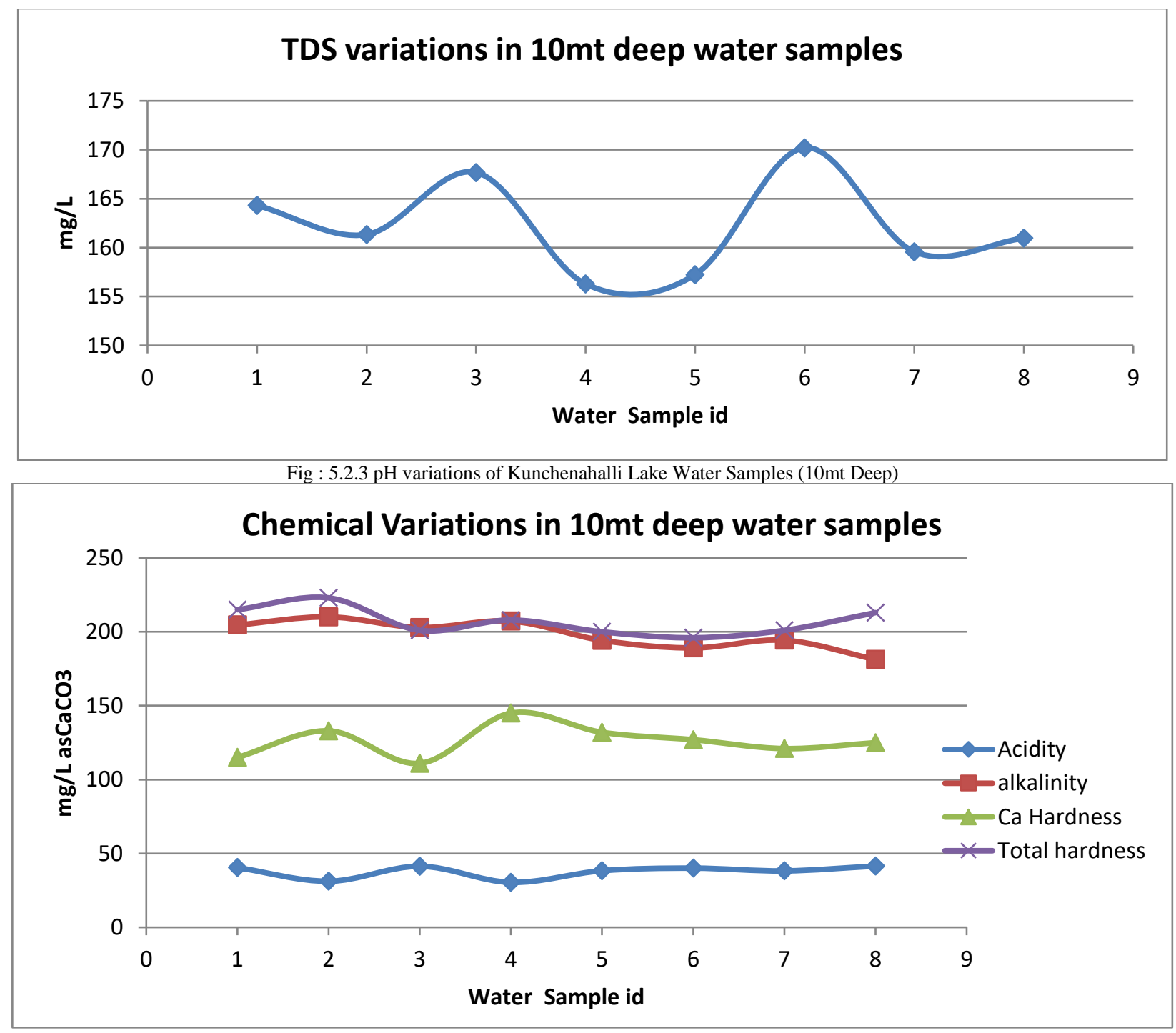

Fig : 5.2.4 Chemical variations of Kunchenahalli Lake Water Samples (10mt Deep)

Similarly the Physico-chemical analysis of Kunchenahalli Lake water samples (samples taken at 10mt depth) exhibited normal distribution (Table 5.2) varying in between 8.5 to 8.9 for $\mathrm{pH}$ (Fig 5.2.2) and varying between $156.28 \mathrm{mg} / \mathrm{L}$ to 170.20 $\mathrm{mg} / \mathrm{L}$ for Total Dissolved Solids (Fig 5.2.3), showing higher than the concentration at the surface level and within permissible BIS standard levels $8.5(\mathrm{pH})$ and $500 \mathrm{mg} / \mathrm{L}$ (TDS). But showed significant high values of Total Hardness i.e., $201 \mathrm{mg} / \mathrm{L}$ to 223 $\mathrm{mg} / \mathrm{L}$ for almost all samples highest being in respect of sample no. 2 (Fig 5.2.4) have been reported against BIS standard limit $(200 \mathrm{mg} / \mathrm{L})$ indicating mineral contamination. Similar results were obtained for Dissolved Oxygen analysis of all water samples at $10 \mathrm{mt}$ depth being reported with less DO varying between $1.31 \mathrm{mg} / \mathrm{L}$ to $1.89 \mathrm{mg} / \mathrm{L}$ (Fig 5.2.1) threatening for the survival of aquatic flora and fauna.

Table 5.3 Heavy Metal analysis of Kunchenahalli Lake Water Samples.

\begin{tabular}{|c|c|c|c|c|c|}
\hline SL NO & $\begin{array}{c}\text { SAMPLE } \\
\text { DETAILS }\end{array}$ & $\begin{array}{c}\text { IRON (Fe) } \\
\mathbf{m g} / \mathbf{L}\end{array}$ & $\begin{array}{c}\text { Zinc(Zn) } \\
\mathbf{m g} / \mathbf{L}\end{array}$ & $\begin{array}{c}\text { Copper(cu) } \\
\mathbf{m g} / \mathbf{L}\end{array}$ & $\begin{array}{c}\text { Manganese } \\
\text { (Mn) } \mathbf{m g} / \mathbf{L}\end{array}$ \\
\hline $\mathbf{0 1}$ & Sample 1 & 2.878 & 0.006 & 0.038 & 2.554 \\
\hline $\mathbf{0 2}$ & Sample 2 & 2.267 & 0.003 & 0.028 & 2.438 \\
\hline $\mathbf{0 3}$ & Sample 3 & 2.280 & 0.001 & 0.024 & 2.502 \\
\hline $\mathbf{0 4}$ & Sample 4 & 2.481 & 0.004 & 0.024 & 2.526 \\
\hline $\mathbf{0 5}$ & Sample 5 & 2.325 & 0.004 & 0.021 & 2.445 \\
\hline $\mathbf{0 6}$ & Sample 6 & 2.241 & 0.003 & 0.032 & 2.598 \\
\hline $\mathbf{0 7}$ & Sample 7 & 2.455 & 0.006 & 0.034 & 2.638 \\
\hline $\mathbf{0 8}$ & Sample 8 & 2.412 & 0.005 & 0.031 & 0.1 \\
\hline $\mathbf{0 9}$ & BIS (max) & 0.3 & 5 & 0.050 & \\
\hline
\end{tabular}




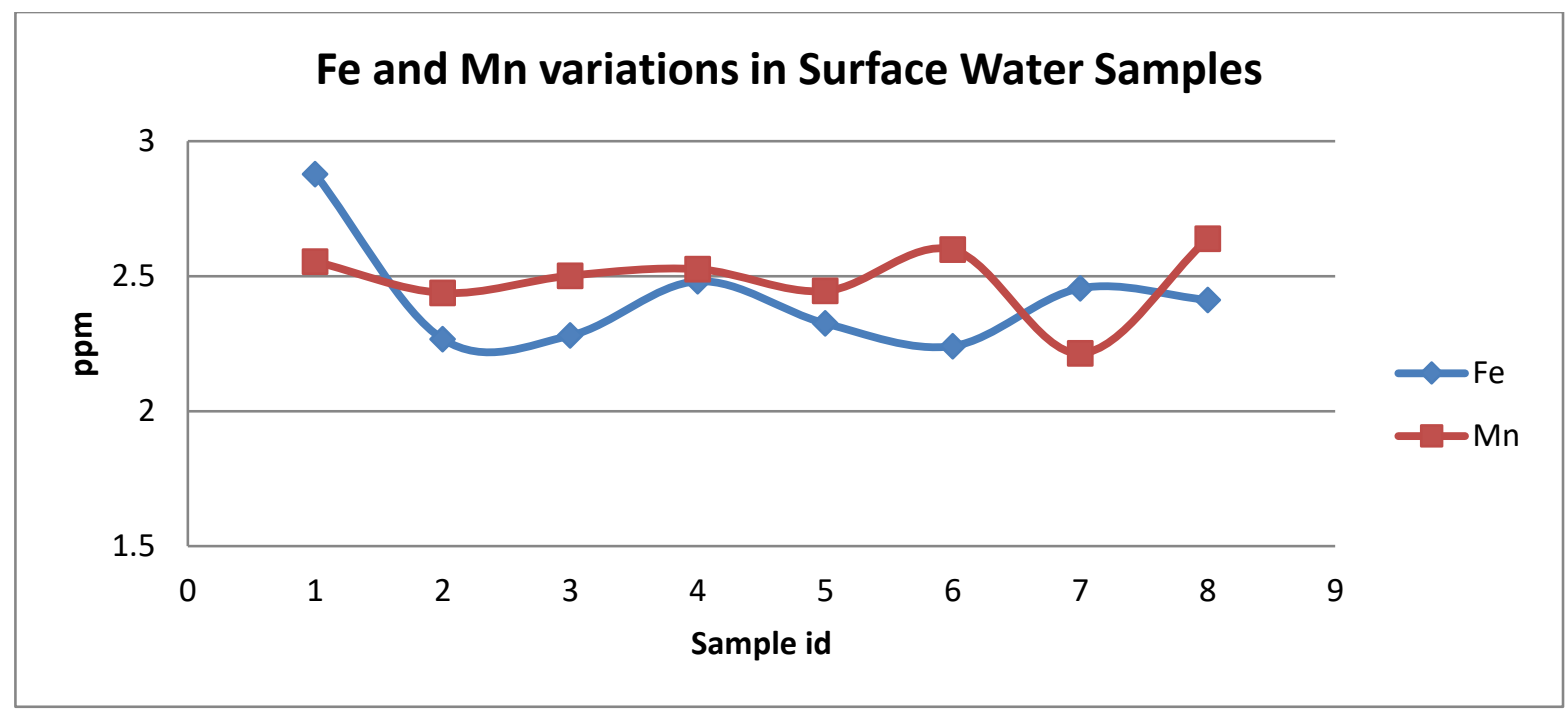

Fig : 5.3.1 Fe and Mn variations of Kunchenahalli Lake Water Samples

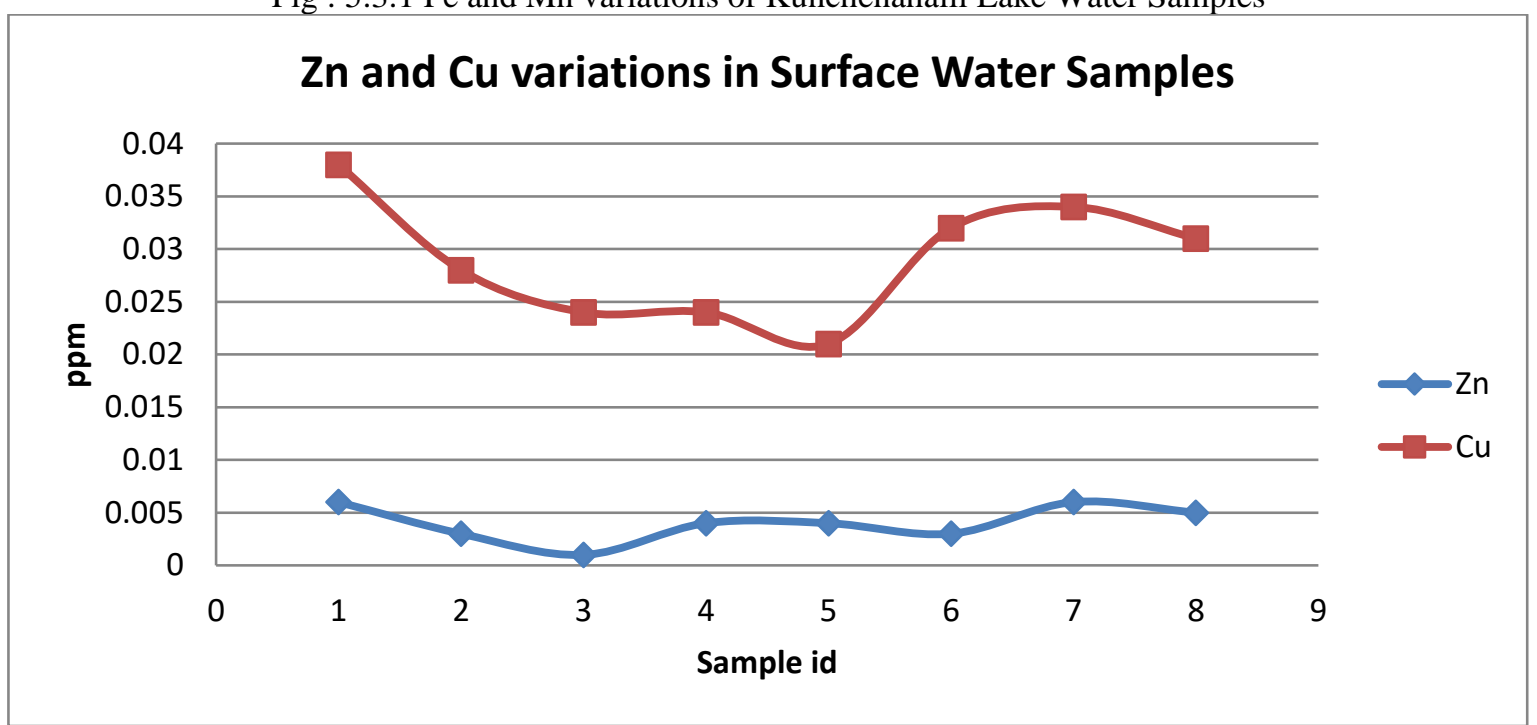

Fig : 5.3.2 $\mathrm{Zn}$ and $\mathrm{Cu}$ variations of Kunchenahalli Lake Water Samples

Heavy metal analysis of Lake water samples (at the surface level) particularly for Fe,Mn, Zn and Cu (Table 5.3) clearly indicates the significant contamination of Lake water with Fe and Mn concentrations much more high varying from 2.241 ppm to $2.878 \mathrm{ppm}$ for Fe and varying from $2.214 \mathrm{ppm}$ to $2.638 \mathrm{ppm}$ for Mn (Fig 5.3.1) against BIS standard limits $0.3 \mathrm{ppm}$ (Fe) and $0.1 \mathrm{ppm}(\mathrm{Mn})$ respectively. Whereas $\mathrm{Zn}$ and $\mathrm{Cu}$ analysis of Lake water samples revealed concentrations well within the BIS standard limits varying from $0.001 \mathrm{ppm}$ to $0.006 \mathrm{ppm}$ for $\mathrm{Zn}$ against limit of $5 \mathrm{ppm}$ (Zn) and varying from $0.021 \mathrm{ppm}$ to 0.038 ppm for $\mathrm{Cu}($ Fig 5.3.2) against limit of $0.050 \mathrm{ppm}(\mathrm{Cu})$.

Table 5.4 Heavy Metal of Kunchenahalli Lake Water Samples at Depth of 10m

\begin{tabular}{|c|c|c|c|c|c|}
\hline SL NO & $\begin{array}{c}\text { SAMPLE } \\
\text { DETAILS }\end{array}$ & $\begin{array}{c}\text { IRON (Fe) } \\
\mathbf{m g} / \mathbf{L}\end{array}$ & $\begin{array}{c}\text { Zinc(Zn) } \\
\mathbf{m g} / \mathbf{L}\end{array}$ & $\begin{array}{c}\text { Copper(cu) } \\
\mathbf{m g} / \mathbf{L}\end{array}$ & $\begin{array}{c}\text { Manganese } \\
\text { (Mn) } \mathbf{~ m g / L ~}\end{array}$ \\
\hline $\mathbf{0 1}$ & Sample 1 & 2.894 & 0.007 & 0.039 & 2.612 \\
\hline $\mathbf{0 2}$ & Sample 2 & 2.281 & 0.004 & 0.024 & 2.467 \\
\hline $\mathbf{0 3}$ & Sample 3 & 2.301 & 0.005 & 0.026 & 2.533 \\
\hline $\mathbf{0 4}$ & Sample 4 & 2.501 & 0.003 & 0.032 & 2.500 \\
\hline $\mathbf{0 5}$ & Sample 5 & 2.351 & 0.002 & 0.026 & 2.435 \\
\hline $\mathbf{0 6}$ & Sample 6 & 2.241 & 0.005 & 0.031 & 2.465 \\
\hline $\mathbf{0 7}$ & Sample 7 & 2.467 & 0.004 & 0.037 & 2.671 \\
\hline $\mathbf{0 8}$ & Sample 8 & 2.552 & 0.005 & 0.046 & 0.1 \\
\hline $\mathbf{0 9}$ & BIS (max) & 0.3 & 5 & 0.050 & \\
\hline
\end{tabular}




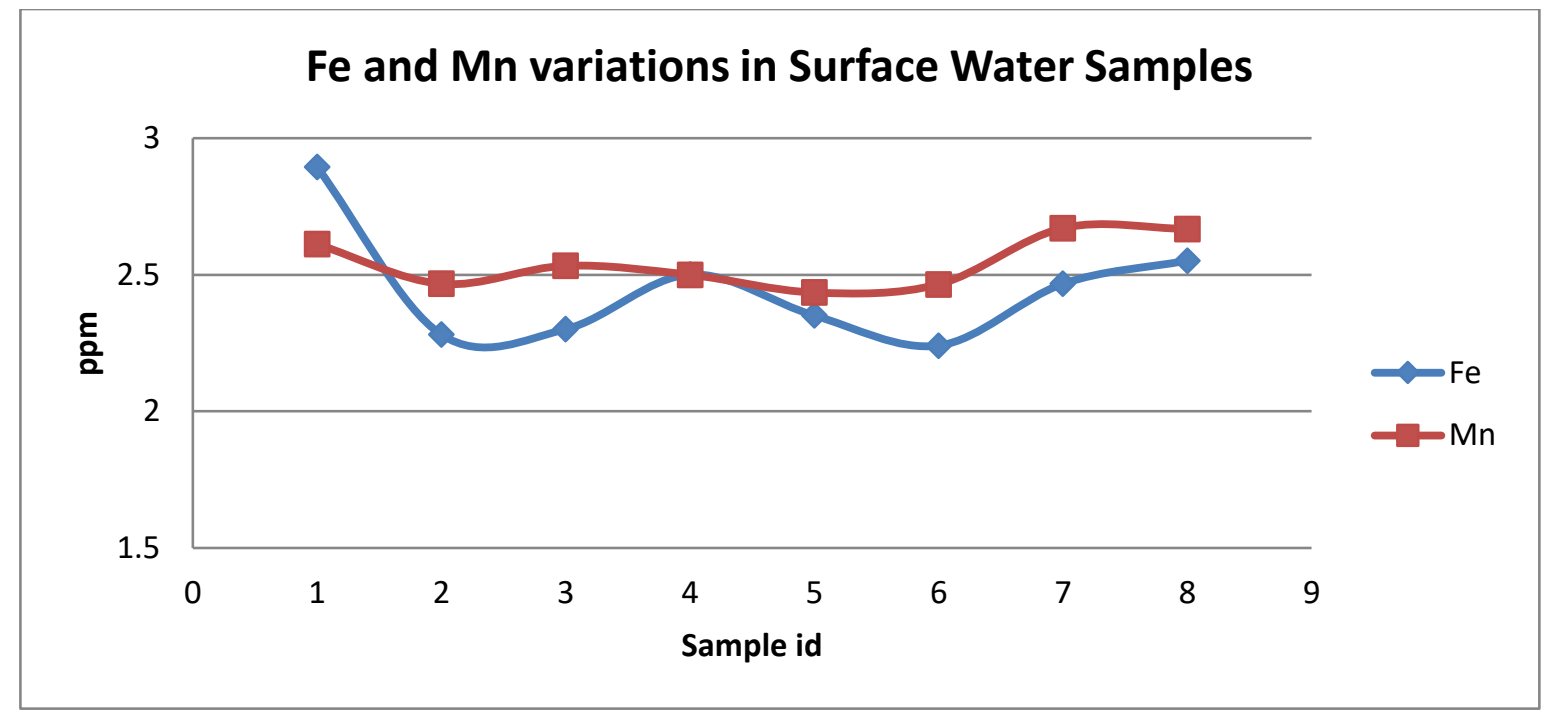

Fig : 5.4.1 Fe and Mn variations of Kunchenahalli Lake Water Samples at 10mt deep

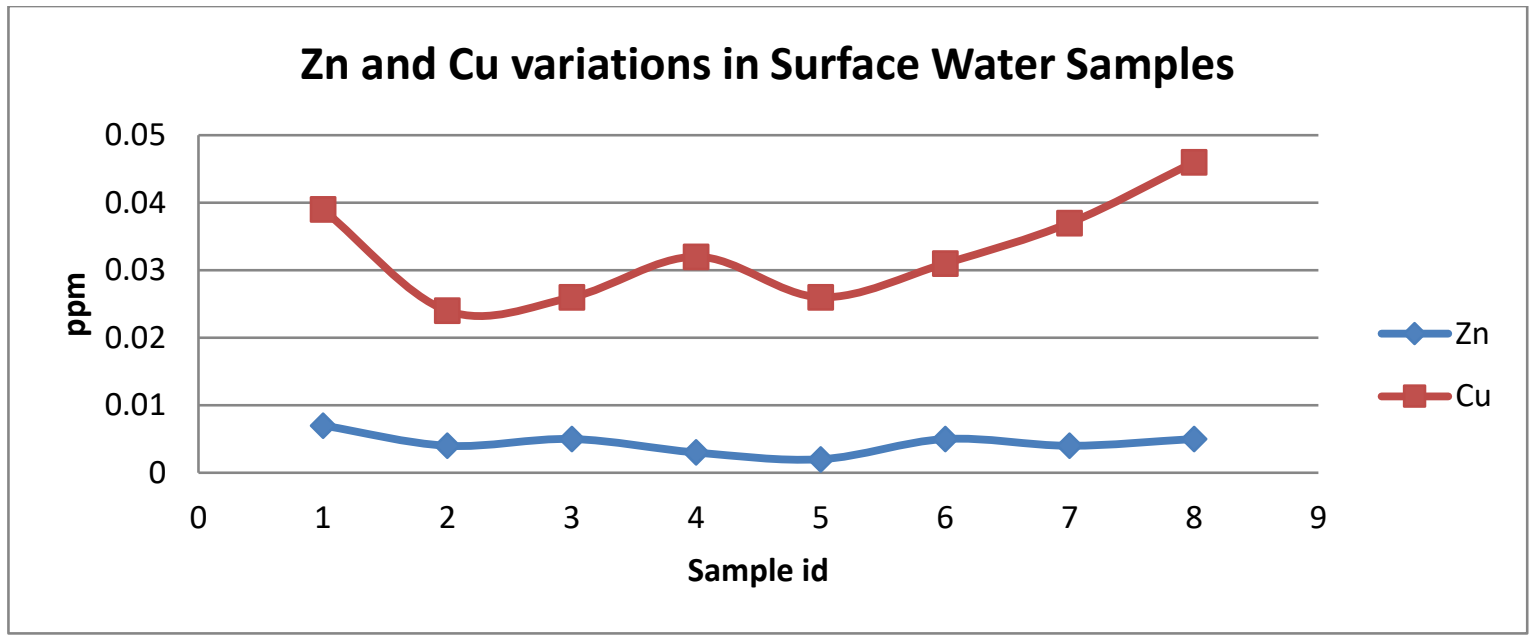

Fig : 5.4.2 Zn and Cu variations of Kunchenahalli Lake Water Samples at 10mt deep

Similar results were obtained in case of heavy metal analysis of Lake water samples (at $10 \mathrm{mt}$ depth) for Fe, Mn, $\mathrm{Zn}$ and $\mathrm{Cu}$ (Table 5.4) pointing the contamination of Lake water with $\mathrm{Fe}$ and $\mathrm{Mn}$ concentrations much more high varying from $2.241 \mathrm{ppm}$ to $2.894 \mathrm{ppm}$ for $\mathrm{Fe}$ and varying from $2.465 \mathrm{ppm}$ to $2.668 \mathrm{ppm}$ for $\mathrm{Mn}$ (Fig 5.4.1) against BIS standard limits 0.3 ppm $(\mathrm{Fe})$ and $0.1 \mathrm{ppm}(\mathrm{Mn})$ respectively. Whereas $\mathrm{Zn}$ and $\mathrm{Cu}$ analysis of Lake water samples revealed concentrations well within the BIS standard limits varying from $0.002 \mathrm{ppm}$ to $0.007 \mathrm{ppm}$ for $\mathrm{Zn}$ against limit of $5 \mathrm{ppm}(\mathrm{Zn})$ and varying from $0.024 \mathrm{ppm}$ to $0.046 \mathrm{ppm}$ for $\mathrm{Cu}$ (Fig 5.4.2) against limit of $0.050 \mathrm{ppm}(\mathrm{Cu})$.

Table 5.5 Heavy Metal analysis of Settled Solids.

\begin{tabular}{|c|c|c|c|c|c|}
\hline SL NO & $\begin{array}{c}\text { SAMPLE } \\
\text { DETAILS }\end{array}$ & $\begin{array}{c}\text { IRON (Fe) } \\
\mathbf{p p m}\end{array}$ & $\begin{array}{c}\text { Zinc(Zn) } \\
\mathbf{p p m}\end{array}$ & $\begin{array}{c}\text { Copper(cu) } \\
\mathbf{p p m}\end{array}$ & $\begin{array}{c}\text { Manganese } \\
\text { (Mn) } \\
\text { ppm }\end{array}$ \\
\hline $\mathbf{0 1}$ & Sample 1 & 30.92 & 18.36 & 0.88 & 7.46 \\
\hline $\mathbf{0 2}$ & Sample 2 & 27.60 & 18.13 & 0.51 & 6.25 \\
\hline $\mathbf{0 3}$ & Sample 3 & 17.40 & 12.50 & 0.28 & 2.36 \\
\hline $\mathbf{0 4}$ & Sample 4 & 25.56 & 15.12 & 0.48 & 4.47 \\
\hline
\end{tabular}




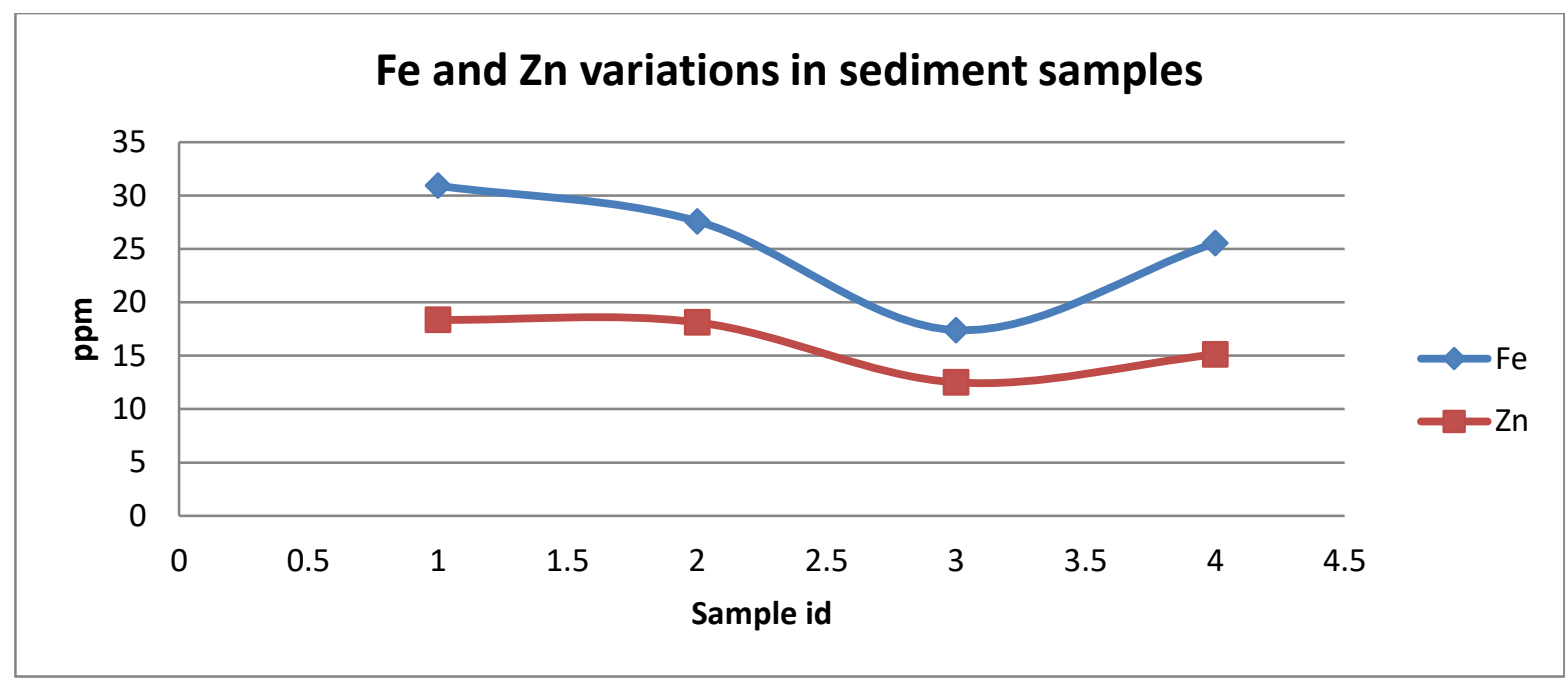

Fig : 5.5.1 Fe and Mn variations of Sediments Samples

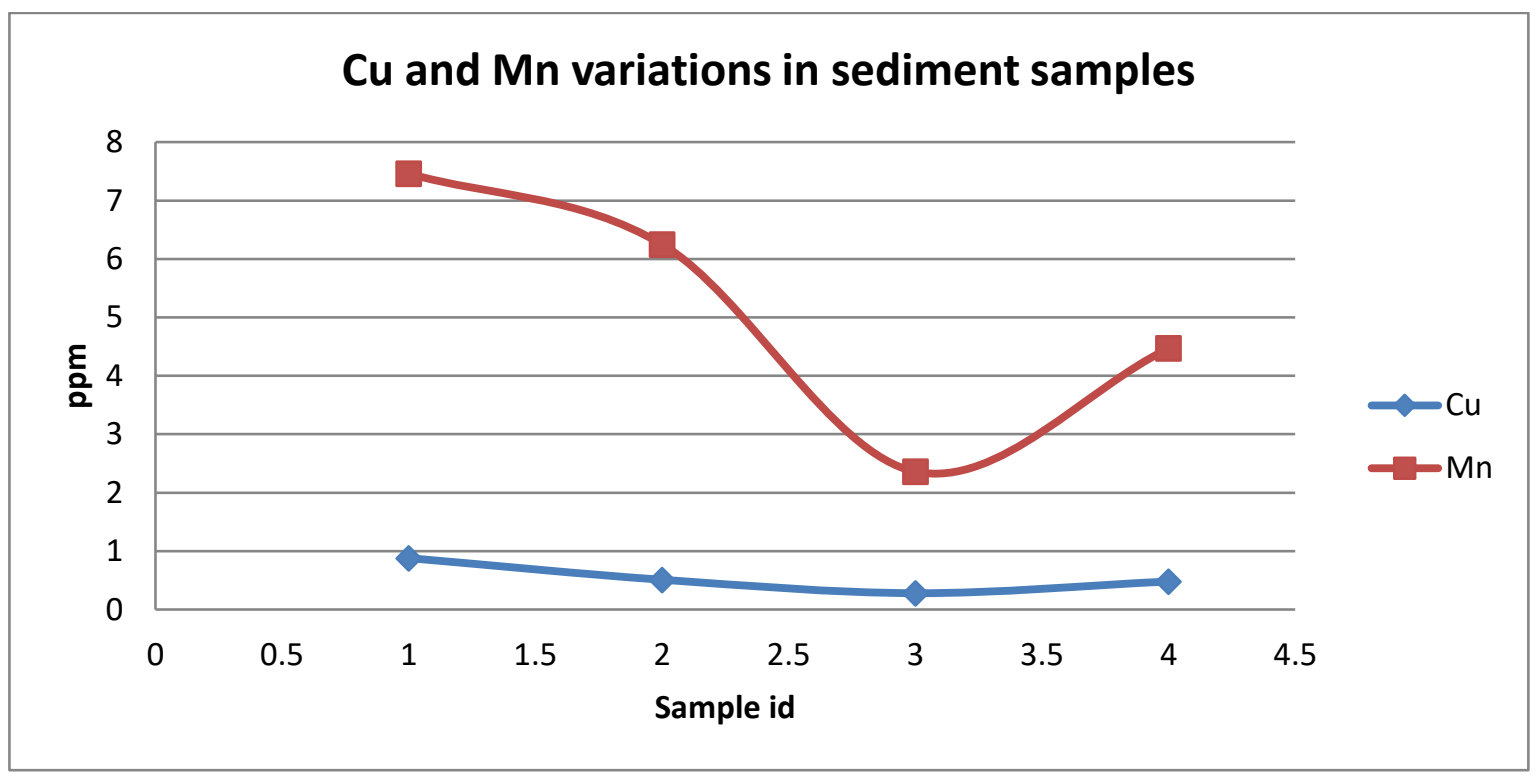

Fig : 5.5.2 $\mathrm{Zn}$ and $\mathrm{Cu}$ variations of Sediments Samples

Further the sediment samples from 4 selected points around the Lake were taken and when subjected to Heavy metal analysis (Table 5.5), Fe concentrations found to vary from $17.40 \mathrm{ppm}$ to $30.92 \mathrm{ppm}$ (Fig 5.5.1), Zn ranged between $12.50 \mathrm{ppm}$ to $18.36 \mathrm{ppm}$ (Fig 5.5.1), $\mathrm{Cu}$ found to vary from $0.28 \mathrm{ppm}$ to $0.88 \mathrm{ppm}$ (Fig 5.5.2) and $\mathrm{Mn}$ ranged between $2.36 \mathrm{ppm}$ to 7.46 ppm (Fig 5.5.2). This sediment analysis has solidified the heavy metal pollution in the Kunchenahalli Lake water body owing to threaten for the useofwater for the domestic purpose. There is a need for action to treat the Lake water and make use of the water body for public usage.

\section{CONCLUSIONS}

The Quantitative and Qualitative conclusions through this study are definitive by itself, the core parameters of chemical and physical characteristics especially Total Hardness and Dissolved Oxygen not comply with the BIS standard limits, which is enough proof that the water source is polluted and this pollution is directly or indirectly related or caused by large amount of Manganese and Iron present in the surrounding area.

Heavy metal analysis conducted by Atomic Absorption Spectrometry clearly proves that manganese and iron are fully concentrated in the surrounding soil which encircle the lake and the amount of these metals leeching into the water results in the content of metal oxides present in the water exceeding the BIS limit standards by Ten to twenty times which is not acceptable. This seeping of metal oxides is due to the environmental factors where surface runoff seeps into the lake due to the bund of soil being at a higher elevation than the Water source which is present at a lower elevation level. The results lead towards the 
necessity of treating the Lake water if it is to put for domestic purpose. The simplest form of treatment would be Oxidation with aeration to precipitate out the Iron and Manganese.

\section{REFERENCES}

[1] APHA. 1995. AMPHA. Standard methods for the examination of water and waste water, $19^{\text {th }}$ edition, American Public Health Association, WashingtonDC.

[2] BIS 1993. Analysis of Water and Waste Water, Bureau of Indian Standards, New Delhi.

[3] BIS 1983. Standards for Water for Drinking and other purposes, Bureau of Indian Standards, New Delhi

[4] Chatterjee, A. A., 1992. Water quality of Nadakanan lake. India., J. Environ. Hlth. 34(4): 329 - 333.

[5] Horton, R.K. 1965. An index number system for rating water quality. Journal of Water Pollution. Cont. Fed. 3:300-305.

[6] Munawar, M., 1970. Limnological studies on fresh water ponds of Hyderabad, India-II, J. Hydrobiologia. 35:127-162.

[7] Naik,S and Purohit, K.M., 1996. Physico-chemical analysis of some community ponds of Rourkela. Indian Journal of Environmental Protection, 16(9): 679-684.

[8] Diersing, Nancy (2009). "Water Quality: Frequently Asked Questions." Florida Brooks National Marine Sanctuary, Key West, FL.

[9] "What are Water Quality Standards?". Washington, D.C.: U.S. Environmental Protection Agency (EPA). 17 March 2016.

[10] R. García and A. P. Báez, Centro de Ciencias de la Atmósfera, Universidad Nacional Autónoma de México,CiudadUniversitaria, Mexico City.

[11] R. García, M. C. Torres and A. Báez. (2008). "Determination of trace elements in total suspended particles at the Southwest of Mexico City from 2003 to 2004". Rev.Chemistry and Ecology. 24(2), Page. 157-167.

[12] Bruvold WH, Ongerth HJ. Taste quality of mineralized water. Journal of the American. Water Works Association, 1969, 61:170.

[13] International Organization for Standardization. Water quality—determination of electrical conductivity. Geneva, 1985 (ISO 7888:1985).

[14] Singh T, Kalra YP. Specific conductance method for in situ estimation of total dissolved solids. Journal of the American Water Works Association, 1975, 67(2):99.

[15] Sawyer CN, McCarty PL. Chemistry for sanitary engineers, 2nd ed. New York, McGrawHill, 1967 (McGraw-Hill Series in Sanitary Science and Water Resources Engineering)

[16] WHO/UNEP, GEMS. Global freshwater quality. Oxford, Alden Press, 1989.

[17] IS : 3025 (Part 23) - 1986 (Reaffirmed 2003)- Methods of Sampling and Test (Physical and chemical) for water and Waste Water.

[18] Speciation of Manganese in Drinking Water, A report - Paul Rumsby, Helen Clegg, Jorgen Jonsson, Victoria Benson, Mark Harman, Tom Doyle, Lesley Rushton (Imperial College Consultants), Peter Warwick (Enviras), David Wilkinson (Enviras), 2014. 